\title{
Serum Zinc, Iron and Copper Concentrations in Dogs Infected with Hepatozoon canis
}

\author{
Kamil Seyrek ${ }^{1}$, Tülin Karagenç², Serdar Paşa ${ }^{3}$, Funda Kıral ${ }^{1}$, Abidin Atasoy ${ }^{3}$ \\ ${ }^{1}$ University of Adnan Menderes, Faculty of Veterinary Medicine, Department of Biochemistry, Aydın, Turkey \\ ${ }^{2}$ University of Adnan Menderes, Faculty of Veterinary Medicine, Department of Parasitology, Aydın, Turkey \\ ${ }^{3}$ University of Adnan Menderes, Faculty of Veterinary Medicine, Department of Internal Medicine, Aydın, Turkey
}

Received July 19, 2008

Accepted February 9, 2009

\begin{abstract}
In Turkey, canine hepatozoonosis is an emerging infection with a large number of cases detected during the past five years. In the present study, serum zinc, copper and iron concentrations of dogs infected with Hepatozoon canis were measured for the first time. Compared to the controls $(\mathrm{n}=10)$, serum zinc and iron concentrations in infected animals $(\mathrm{n}=14)$ decreased significantly ( $p<0.05$ and $p<0.01$, respectively), whereas the concentrations of copper in diseased animals increased significantly $(p<0.05)$. In conclusion, the results of the present study indicate that Hepatozoon canis infection may cause alterations in serum zinc iron and copper concentrations. Furthermore, in the treatment of infected animals addition of zinc and iron to the ration of infected animals should be taken into consideration.
\end{abstract}

Hepatozoonozis, dog, trace minerals

Canine hepatozoonozis afflicts dogs in Asia, Africa, Southern Europe, South America and North America (Forlano et al. 2005). The main vector of the disease is the brown dog tick, Rhipicephalus sanguineus (Baneth et al. 2001). In Turkey, canine hepatozoonosis was reported for the first time by Tüzdil (1933) and it is expanding on the Aegean coast. H. canis lives in several cell types (such as muscular, hepatic or haematic) of canids and felids. Infection has been reported to be associated with a variety of clinical signs ranging from sub-clinical infection to a severe life threatening disease with distinct haematological, biochemical and histopathological alterations (Baneth and Weigler 1997; Criado-Fornelio et al. 2007; Eiras et al. 2007; Gavazza et al. 2003). Fever, anorexia, weight loss, anaemia, ocular discharge and weakness of the limbs are some of the clinical signs (Baneth and Weigler 1997; Criado-Fornelio et al. 2007; Forlano et al. 2005). Haematological and biochemical abnormalities are anaemia, leukocytosis, thrombocytopaenia, hypoalbuminaemia, hyperglobulinaemia and increased serum alkaline phosphatase activity (Baneth and Weigler 1997). Histopathologically parasite-containing lesions can be found in many tissues such as in striated muscle, liver, lymph nodes, spleen and in pancreas (Ewing and Panciera 2003).

Studies on most micronutrients are complicated by the fact that the nutrient is multifunctional. For example, zinc is required in over 200 enzymes and so deficiency is likely to affect a number of different systems (Evans and Halliwell 2001). Zinc contributes to structure and function of important metalloenzymes, including carbonic anhydrase, alkaline phosphatase, RNA and DNA polymerases, and alcohol dehydrogenase (Gabor 1989). T-cell mediated responses are critical for host protection against parasitic infections (Shi et al. 1998) and any impairment of T cells or the cells that present antigen to them, caused by zinc deficiency, is therefore expected to cause a decrease in host protection. Yet, surprisingly few studies have examined the effect of dietary zinc deficiency on hostparasite interactions (Shi et al. 1998).

Address for correspondence:

Assoc. Prof. Dr. Kamil Seyrek

University of Adnan Menderes

Faculty of Veterinary Medicine

Department of Biochemistry

PK 1709016 Isikli-AYDIN/TURKEY
Phone: 0090 2562470700/173

GSM: 00905323075704

Fax: 00902562470720

E-mail:kmseyrek@hotmail.com

http://www.vfu.cz/acta-vet/actavet.htm 
Iron is a component of a number of metabolic enzymes, so it is needed for basic metabolic activities of cells (Miller 1985). Even for intracellular survival of some parasites an adequate supply of iron is required (Marquis and Gros 2007). Iron is a co-factor for superoxide dismutase, which protects cells against toxic oxygen species (Marquis and Gros 2007). In mammalian cells, iron is mostly present as poorly soluble $\mathrm{Fe}^{3+}$, which is tightly bound to transferrin for transport or to ferritin for storage (Marquis and Gros 2007). Iron is also essential as a component of haemoglobin in red blood cells to prevent anaemia.

Copper is an essential trace element for all organisms, due to its action as a co-factor in many enzymes, but it is also potentially toxic because, like iron, copper can donate or receive electrons (Rasolos on et al. 2004). Copper is required for caeruloplasmin, which loads iron onto transferrin (Evans and Halliwell 2001). Increased plasma copper concentrations have been found in infectious processes; thus, following serum $\mathrm{Cu}$ concentrations is a useful monitor for some diseases (Pasa et al. 2003; Schroeder et al. 1967).

On the Aegean coast, canine hepatozoonosis is an emerging infection with a large number of cases detected during the past recent years (Karagenc et al. 2006). To the best of our knowledge, the serum concentrations of trace elements have not been reported previously in dogs infected with $H$. canis. To this end, in the present study, we intended to measure serum zinc, copper and iron concentrations in dogs infected with $H$. canis.

\section{Materials and Methods}

Animals

Fourteen dogs infected with $H$. canis along with 10 healthy dogs were used in this study. All the animals, aged two to eight years, were mixed-breed dogs. Diagnosis of the infection was performed by microscopical examination of gametocytes in neutrophil-like cells in peripheral blood as well as using molecular techniques including the polymerase chain reaction (PCR) and sequence analyses in the first part of this study (Kiral et al. 2005) related information was given explicitly. Twelve of the diseased dogs were female and two were male. Seven of the control animals were female and three were male. All of the infected dogs showed some or all of the clinical signs of the disease, including fever, lethargy, weight loss, stiffness, and signs of pain, paralysis and ocular discharge.

The study was approved by the Adnan Menderes University Animal Use and Care Committee.

Biochemical analysis

Blood samples were taken from the cephalic vein and centrifuged at 2,400 $\mathrm{g}$ for $10 \mathrm{~min}$. The serums were collected in plastic tubes and stored at $-20{ }^{\circ} \mathrm{C}$ until analyses. Serum zinc, iron and copper concentrations were measured using commercial available kits (Randox Laboratories, UK) with a spectrophotometer (Shimadzu, UV-1601). The analyses were carried out according to the manufacturer's instructions.

Statistical Analysis

The data were analysed using Student's $t$-test and Pearson correlation coefficient (SPSS Version 12.0), and $P<0.05$ was considered significant.

\section{Results}

As shown in Table 1, the mean serum concentrations of zinc in healthy animals were $62.05 \pm 7.59 \mu \mathrm{g} / \mathrm{dl}$. Serum concentrations of zinc in diseased animals, however, decreased significantly $(p<0.05)$ to $36.33 \pm 8.02 \mu \mathrm{g} / \mathrm{dl}$. Similarly, a significant $(p<0.01)$ decrease in iron concentrations of infected animals was observed. The mean serum iron levels of infected animals declined from $86.03 \pm 19.88 \mu \mathrm{g} / \mathrm{dl}$ to $57.62 \pm 7.46 \mu \mathrm{g} / \mathrm{dl}$. Serum copper concentrations in diseased animals, however, increased significantly $(p<0.05)$ from 100.60 $\pm 1.18 \mu \mathrm{g} / \mathrm{dl}$ to $135.67 \pm 8.67 \mu \mathrm{g} / \mathrm{dl}$.

Table 1. Comparison of some serum trace elements in dogs with Hepatozoon canis and healthy animals

\begin{tabular}{|l|c|c|c|c|c|}
\hline Indicators & $\mathrm{N}$ & Controls & $\mathrm{n}$ & Hepatozoon canis & $P$ \\
\hline Zinc $(\mu \mathrm{g} / \mathrm{dl})$ & 10 & $62.05 \pm 7.59$ & 14 & $36.33 \pm 8.02$ & $<0.05$ \\
\hline Iron $(\mu \mathrm{g} / \mathrm{dl})$ & 10 & $86.03 \pm 19.88$ & 14 & $57.62 \pm 7.46$ & $<0.01$ \\
\hline Copper $(\mu \mathrm{g} / \mathrm{dl})$ & 10 & $100.60 \pm 1.18$ & 14 & $135.67 \pm 8.67$ & $<0.05$ \\
\hline
\end{tabular}

$* P<0.05, * * P<0.01$ 


\section{Discussion}

There is considerable evidence for interactions between parasitic diseases and essential trace elements (Filteau and Tomkins 1990). Two general types of abnormality of trace element status can be identified: a specific deficiency arising from dietary inadequacies (Forlano et al. 2007) and imbalance resulting from the disease (Forlano et al. 2005). In both cases, trace element status can be adequately assessed by serum elemental analysis (Klasing 1988).

Infection with $\mathrm{H}$. canis causes a distinct clinical syndrome characterised by fever, anorexia, weight loss, anaemia, ocular discharge and weakness of the limbs (Baneth et al. 2003; Vincent-Johnson et al. 1997). The ability of animals to cope with parasitic infection may be influenced by mineral nutrition, in particular $\mathrm{Zn}, \mathrm{Cu}$ and $\mathrm{Fe}$ of the trace elements (Miller 1985). Deficiency of some trace minerals may weaken host protection and result in elevated parasite numbers (Shi et al. 1998). The extent of the impairment in host protection due to trace element deficiency can be sufficient to increase the risk of morbidity and mortality due to parasitic infections and reversal of trace element deficiency may restore impaired host protection. However, the serum concentrations of trace elements have not been reported previously in dogs infected with $H$. canis. This might be in part due to the relatively low incidence of hepatozoonosis.

Low serum zinc levels have been reported in parasitic diseases (Tasci et al. 1995). Decreased zinc concentrations in diseased animals found in the present study are in line with this finding. According to previous reports, parasites in the host are dependent on zinc for many metabolic and biochemical pathways (Scott and Koski 2000). For example, some parasitic nematodes have exceptionally high concentrations of zinc-dependent superoxide dismutase (Clark et al. 1986), and schistosome worms have been shown to have particularly high uptakes of zinc relative to host tissue, suggesting that they may have a particularly high need for this molecule, so the reason of low levels of zinc in infected dog may be due to the high uptake of zinc by H. canis. However, on the other hand, dogs infected with $H$. canis are at risk of protein-energy malnutrition, as well as deficiencies in micronutriens including zinc. Therefore, it is not clear whether depression in serum zinc concentrations in infected animals originated from malnutrition or from the high uptake of zinc by $H$. canis. This question needs to be pursued.

The trace element concentrations in serum samples change during infection (Pasa et al. 2003; Wagner et al. 1991). These changes are part of the defence strategies of the organism, induced by IL-1, IL-6, and TNF- $\alpha$ (Klasing 1988; Wagner et al. 1991). The removal of iron from circulation results from the production of apolactoferrin removing Fe-transferrin and sequestering iron in compartments that are nutritionally unavailable to parasites. On the other hand, it is reported that iron is needed for basic metabolic activity but is also required as a co-factor for superoxide dismutase, which protects certain intracellular parasites against toxic oxygen species generated by the phagocyte NADPH oxidase (Marquis and Gros 2007). However, from this statement it cannot be concluded whether the reason of the decreased serum iron level in infected animals is the use of iron by the intracellular parasite or its diversion to other parts of the body. We suggest that studies be conducted to investigate in more depth the mechanisms by which iron concentrations declined.

Contrary to the decreased levels of zinc and iron, a significant increase in serum copper concentration of sick animals was observed. Although plasma copper concentrations are commonly used as a surrogate marker of copper status in many clinical trials, plasma copper represents a very small amount of total body copper stores, and there is a poor correlation between plasma copper concentrations and body stores (Jackson 1989). To this end, increased levels of serum copper may be explained with a relocation of copper, decrease in stores and reciprocal increase in circulating copper. Furthermore, increased 
serum copper concentration in infected animals observed in the present study is consistent with the previous findings that host leukocyte-induced metabolic changes resulting in an increase of serum copper (Delacruz et al. 1993; Pasa et al. 2003).

In conclusion, alterations in serum zinc, iron and copper concentrations in diseased animals may depend on $H$. canis infection. However, studies concerning the alterations in concentrations of trace elements in parasitic diseases are complicated by the fact that the trace elements are multi-functional. To this end, the monitoring of trace element concentrations in infected animals especially with treatment opportunity may be helpful to clarify the reason of alterations in trace elements in dogs with $H$. canis.

\section{Sérové koncentrace zinku, železa a mědi u psů s onemocněním Hepatozoon canis}

Hepatozoonóza psů je v Turecku novým onemocněním, jehož výskyt byl v posledních pěti letech detekován u značného počtu jedinců. V této studii byla poprvé sledována sérová koncentrace zinku, mědi a železa v souvislosti s infestací psů druhem Hepatozoon canis. V porovnání s kontrolní skupinou psů $(\mathrm{n}=10)$, byly u nakažených jedinců $(\mathrm{n}=14)$ sníženy sérové koncentrace zinku $(p<0.05)$ a železa $(p<0.01)$, zatímco koncentrace mědi v séru se výrazně zvýšila $(p<0.05)$.

Výsledky naší studie dokazují, že nákaza Hepatozoon canis může vyvolat změny sérových koncentrací zinku, železa a mědi. Zároveň je vhodné vzít v úvahu možnost přidávat železo a zinek do krmné dávky během terapie psů nakažených hepatozoonózou.

\section{References}

Baneth G, Weigler B 1997: Retrospective case-control study of hepatozoonosis in dogs in Israel. J Vet Intern Med 11: $365-370$

Baneth G, Samish M, Alekseev E, Aroch I, Shkap V 2001: Transmission of Hepatozoon canis to dogs by naturallyfed or percutaneously-injected Rhipicephalus sanguineus ticks. J Parasitol 87: 606-611

Baneth G, Mathew JS, Shkap V, Macintire DK, Barta JR, Ewing SA 2003: Canine hepatozoonozis: two disease syndromes caused by separate Hepatozoon spp. Trends Parasitol 19: 27-31

Clark IA, Hunt NM, Cowden WB 1986: Oxygen derived free radicals in the pathogenesis of parasitic diseases. Adv Parasitol 25: 1-44

Criado-Fornelio A, Rey-Valeiron C, Buling A, Barba-Carretero JC, Jefferies R, Irwin P 2007: New advances in molecular epizootiology of canine hematic protozoa from Venezuela, Thailand and Spain. Vet Parasitol 144: 261-269

Delacruz AJMD, Burguera LJ, Burguera M, Anez N 1993: Changes in the total content of iron, copper and zinc in serum, heart, liver, spleen and skeletal muscle tissues of rats infected with Trypanasoma cruzi. Biol Trace Elements Res 37: 51-70

Eiras DF, Basabe J, Scodellaro CF, Banach DB, Matos ML, Krimer A, Baneth G 2007: First molecular characterization of canine hepatozoonozis in Argentina: evaluation of asymptomatic Hepatozoon canis infection in dogs from Buenos Aires. Vet Parasitol 149: 275-279

Evans P, Halliwell B 2001: Micronutrients: oxidant/antioxidant status. Br J Nutr 85: 67-74

Ewing SA, Panciera RJ 2003: American Canine Hepatozoonosis. Clin Microbiol Rev 16: 688-697

Filteau SM, Tomkins AM 1994: Micronutrients and tropical infections. Trans R Soc Trop Med Hyg 88: 1-3

Forlano M, Scofield A, Elisei C, Fernandes KR, Ewing SA, Massard CL 2005: Diagnosis of Hepatozoon spp. in Amblyomma ovale and its experimental transmission to domestic dogs in Brazil. Vet Parasitol 134: 1-7

Forlano MD, Teixeira KRS, Scofield A, Elisei C, Yotoko KSC, Fernandes KR, Linhares GFC, Ewing SA, Massard CL 2007: Molecular characterization of Hepatozoon sp. from Brazilian dogs and its phylogenetic relationship with other Hepatozoon spp. Vet Parasitol 145: 21-30

Gabor S 1989: Trace elements and lipid peroxidation. In: Trace elements in health and disease. Yuregir GT, Donma O, Kayrin L (Eds): Adana, Turkey, March 31, April 8, 1989, C U Pub Trace 89: 273-277

Gavazza A, Bizetti M, Papini R 2003: Observations on dogs found naturally infected with Hepatozoon canis in Italy. Revue Med Vet 154: 565-571

Jackson MJ 1989: Physiology of zinc: general aspects. In Mills, CF (Ed.): Zinc in Human Biology. SpringerVerlag, London, pp. 1-10

Karagenc TI, Pasa S, Kirli G, Hosgor M, Bilgic HB, Ozon YH, Atasoy A, Eren H 2006: A parasitological, molecular and serological survey of Hepatozoon canis infection in dogs around the Aegean coast of Turkey. Vet Parasitol 135: 113-119

Kiral F, Karagenc T, Pasa S, Yenisey C, Seyrek K 2005: Dogs with Hepatozoon canis respond to the oxidative stress by increased production of glutathione and nitric oxide. Vet Parasitol 131: 15-21 
Klasing KC 1988: Nutritional aspects of leukocytic cytokines. J Nutr 118: 1436-1446

Marquis JF, Gros P 2007: Intracellular Leishmania: your iron or mine.Trends Microbiol 15: 93-95

Miller ER 1985: Mineral × Disease interactions. J. Anim Sci 60: 1500-1507

Pasa S, Kargin F, Bildik A, Seyrek K, Ozbel Y, Ozensoy S 2003: Serum and hair levels of zinc and other elements in dogs with visceral leishmaniasis. Biol Trace Elem Res 94: 141-147

Rasoloson D, Shi L, Chong CR, Kafsack BF, Sullivan DJ 2004: Copper pathways in Plasmodium falciparum infected erythrocytes indicate an efflux role for the copper P-ATPase. Biochem J 381: 803-811

Schroeder HA, Nason AP, Tipton IH, Balassa JJ 1967: Essential trace metals in man: zinc. Relation to environmental cadmium. J Chronic Dis 19: 179-210

Scott ME, Koski KG 2000: Zinc deficiency impairs immune responses against parasitic nematode infections at intestinal and systemic sites. J Nutr 130: 1412-1420

Shi HN, Scott ME, Stevenson MM, Koski KG 1998: Energy restriction and zinc deficiency impair the functions of murine T cells and antigen-presenting cells during gastrointestinal nematode infection. J Nutr 128: 20-27

Tasci S, Sengil AZ, Altindis M, Arisoy K 1995: The effect of zinc supplementation in experimentally induced Toxoplasma gandii infection. J Egypt Soc Parasitol 25: 745-751

Tuzdil AN 1933: Bizde ilk defa görülen bir Hepatozoon canis vak'ası [in Turkish]. Türk Baytarlar Cemiyeti Mecmuası 13: 35

Vincent-Johnson N, MacIntire DK, Baneth G 1997: Canine hepatozoonozis: pathophysiology, diagnosis, and treatment. Compend Educ Prac Vet 19: 51-65

Wanger HM, Buesher HU, Rollinghoff M, Solbach W 1991: Interferon-gamma inhibits the efficacy of interleukin-1 to generate a $\mathrm{Th}_{2}$-cell biased immune response induced by Leishmania major. Immunobiology 182: $292-306$ 